\title{
Development of building exploitation programs in the concept of energy-sustainable urban development
}

\author{
Marina Dement'eva ${ }^{1, *}$ \\ ${ }^{1}$ Moscow State University of Civil Engineering, 129337, Yaroslavskoe shosse, 26, Moscow, Russia
}

\begin{abstract}
In the life of every major metropolis, there comes a time when it is impossible to reach new levels of development without the use of innovative technologies. They are necessary to optimize ongoing processes in the urban environment and ensure energy-sustainable urban development. The purpose of the study was to develop a model of an exploitation program designed to monitor and ensure the safe and energy efficient exploitation of buildings and assess the quality of work of managing organizations. The relevance of the study is justified, on the one hand, by the lack of a unified system of planning and quality control of building management, and, on the other hand, by the need to use information technologies as part of the Digital Economy of the Russian Federation program for successful planning of a sustainable urban environment. The object of research was the process of technical operation of buildings. The subject of the study was the study of the principles of the formation of building maintenance programs based on information technologies taking into account energy efficiency requirements. One of the significant results of the study is the developed algorithm for the formation of a building maintenance program for deciding on corrective maintenance measures. Criteria are proposed for assessing the quality of managing the safety and comfort of a building, which can be taken into account when developing voluntary national standards in the field of "green" construction.
\end{abstract}

\section{Introduction}

Today, the sustainable development of cities cannot be imagined without the integration of information, communication and energy efficient technologies in the urban infrastructure management system, which in the global sense is aimed at increasing the level of comfort, quality and efficiency of public services, reducing costs and resource consumption [1,2]. The strategic concept of an integrated approach to the development of cities "Smart City" can help in solving the problems of effective management of the urban environment, which involves the optimal organization of the entire life of the city. In particular, in 2017, the Russian government approved the program "Digital Economy of the Russian Federation",

\footnotetext{
* Corresponding author: 7dem@mail.ru
} 
which includes the creation of "Smart Cities". At present, it is customary to highlight several key areas in the strategy of sustainable urban development, including through the use of digital technologies that can be introduced into the exploitation of buildings for the implementation of corrective control actions (Fig. 1).

\begin{tabular}{|c|c|c|}
\hline $\begin{array}{l}\text { Development } \\
\text { directions }\end{array}$ & City evolution mechanisms & $\begin{array}{l}\text { Control effects on the quality of } \\
\text { exploitation of buildings }\end{array}$ \\
\hline $\begin{array}{c}\text { Smart Energy } \\
\text { and Smart Grids }\end{array}$ & $\begin{array}{l}>\text { Energy Regulation } \\
>\text { Demand management } \\
>\text { Energy saving } \\
>\text { Renewable Energy Integration }\end{array}$ & $\begin{array}{l}\checkmark \text { Automated monitoring and control of } \\
\text { lighting, heating, ventilation, air } \\
\text { conditioning systems }\end{array}$ \\
\hline Smart Water & $\begin{array}{l}>\text { Modernization of water systems } \\
>\text { Consumption monitoring } \\
>\text { Environmental safety monitoring } \\
>\text { Flood management }\end{array}$ & $\begin{array}{l}\checkmark \text { Real-time automated consumption } \\
\text { monitoring } \\
\checkmark \text { Leak prevention } \\
\checkmark \text { Consumption Optimization }\end{array}$ \\
\hline Smart Buildings & $\begin{array}{l}\text { Integration of engineering and } \\
\text { information systems with city } \\
\text { services } \\
\text { Automated management of } \\
\text { energy saving, comfort and safety }\end{array}$ & $\begin{array}{l}\checkmark \text { Automation, management and control } \\
\text { of resource consumption } \\
\checkmark \text { Security control } \\
\checkmark \text { Garbage disposal management } \\
\checkmark \text { Monitoring the technical condition of } \\
\text { the building } \\
\checkmark \text { Operational planning } \\
\checkmark \text { Control of financial flows } \\
\checkmark \text { Organization of workflow } \\
\end{array}$ \\
\hline $\begin{array}{c}\text { Smart } \\
\text { Transportation } \\
\end{array}$ & \multicolumn{2}{|c|}{$\begin{array}{l}>\text { Monitoring and traffic management, traffic lights, parking } \\
>\text { Emergency response }\end{array}$} \\
\hline $\begin{array}{c}\text { Smart } \\
\text { Government }\end{array}$ & \multicolumn{2}{|c|}{$\begin{array}{l}>\text { Optimization of the work of city departments, development of public } \\
\text { services (healthcare, education, culture, social services, security) }\end{array}$} \\
\hline
\end{tabular}

Fig. 1. Strategic directions for sustainable urban development based on digital technologies.

Obviously, digital technologies play one of the leading roles, including when creating models of modern buildings and when managing in the construction sector [3-5]. It is assumed that such models should be developed by updating information throughout the life cycle of buildings. At the same time, at present, the most widely used information models are used at the design stage [6], to visualize data about the object, as well as to control project risks [7-10]. To a lesser extent, they are used at the construction stage and are practically not used for data management during the exploitation phase of the buildings [11-13]. Consider the problems of digital technology in the exploitation of buildings.

The first problem is that at present the information model most often represents a set of geometric elements, and other information, including characteristics of elements, documents, albeit structured, but stored separately.

The second problem is the almost complete absence of a transition from one stage of the building's life cycle to another, that is, each stage to begin anew. There are isolated cases of an independent audit of the design process using an information model, which made it possible to control the design and implementation of the project, and then generate all the necessary documentation to obtain permission to put the facility into operation. However, the process did not go beyond this.

The third problem is a misunderstanding of how the information model can be applied in the exploitation process. On the one hand, it is presented as a kind of system that allows you to create a package of documents for the next stage of the life cycle of an object. On 
the other hand, the information model is presented as an object dispatching system that allows responding to emergencies and reducing unproductive losses of resources [14]. However, paperwork and automation of engineering systems is only a small part of the complex exploitation process.

It must be understood that digital technologies should help make effective decisions on managing the exploitation process based on the study of information flows to reduce risks in the urban economy. Thus, the information model should be a tool, designed ultimately to assess the changes that occur with the building during the long phase of exploitation.

Given the many difficulties and problems that exist in the field of housing and communal services [15-18] and adversely affect the sustainable development of the city, the issue of developing and introducing digital technologies into the work of managing organizations is an urgent task and justifies the relevance of this study. The hypothesis of the study lies in the need to develop programs for building maintenance on the basis of digital technologies as part of the development of the concept of sustainable urban development, which will depend on the degree of wear of the building.

The aim of the study was to develop a model of an operational program designed to make managerial decisions to ensure the quality of the functioning of the building and assess the quality of management companies. To achieve this goal, it was necessary to solve the following tasks:

1. Perform a qualitative analysis of the problems of implementing digital technologies at the stage of exploitation of buildings.

2. To propose an algorithm for generating and updating data on changes in the state of a building.

3. To propose a methodology for the formation of an exploitation program for the effective management of the technical condition of the building as part of sustainable urban planning.

\section{Materials and Methods}

The object of research was the process of managing the technical exploitation of the building in terms of ensuring its safety, quality and energy efficiency. The subject of the study was the study of the principles of the formation of building maintenance programs based on digital technologies. The following assumptions were made in the work:

1. The exploitation phase is understood as the time interval from the moment of execution of documents on the commissioning of the building to the time of disposal of the building.

2. This time interval may include such exploitation measures as exploitation control, maintenance, current and major repairs, modernization, reconstruction, conservation, utilization of a building.

3. The maintenance program is a part of the building's information model, filled out during the exploitation phase, which is constantly updated by entering data obtained during all the above operational activities.

4. The purpose of the development of the exploitation program is the adoption and justification of an effective decision on the selection of the necessary operational measures.

5. Information accumulated as part of the exploitation program should have full navigation and the ability to be accessible to it both by the managing organization and the owners of the building.

These assumptions formed the basis for the development of the methodology for the formation of the exploitation program, which included the following stages:

- establishment of a list of building information requiring updating;

- determination of the type of activities to obtain the required information; 
- selection of methods for obtaining and processing data;

- assessment of the results;

- analysis of the need to adjust operational measures.

Given the versatility of the research, the selection of methods for obtaining and processing information should be based on the following principles:

- objectivity of the information received;

- correspondence of the type of event and diagnostic method to the objectives of the study;

- obtaining integral quality indicators;

- the desire to obtain quantitative indicators;

- use of quality indicators;

- independence of the methods used.

\section{Results}

In accordance with the objectives of the study, a qualitative analysis of the obstacles to the implementation of digital technologies at the stage of building exploitation was performed, the results of which are presented in Table. 1.

Table 1. Classification of the problems of introducing digital technologies during the exploitation phase of a building.

\begin{tabular}{|c|c|}
\hline $\begin{array}{l}\text { Nature of origin of } \\
\text { the problem }\end{array}$ & Problem content \\
\hline High financial costs & $\begin{array}{l}\text { - Cost of procurement, maintenance, and software updates } \\
\text { - Cost of purchasing more productive equipment } \\
\text { - The cost of training, continuing education }\end{array}$ \\
\hline Additional labor costs & $\begin{array}{l}\text { - Time to train to the level of self-confident digital work } \\
\text { - Time to gain experience and consolidate skills }\end{array}$ \\
\hline Extra time costs & $\begin{array}{l}\text { - Time to detail the exploitation project } \\
\text { - Time to complete the project in accordance with the standards } \\
\text { - Time to coordinate the interaction of project participants }\end{array}$ \\
\hline Social interaction & $\begin{array}{l}\text { - Orientation of existing educational programs to training in traditional } \\
\text { - } \text { Cothods of exploitation } \\
\text { - Frequent change of management organizations } \\
\text { - High staff turnover in the field of housing and communal services } \\
\text { - Lack of a digital standard for the coordination of exploitation process } \\
\text { participants for linking management decisions }\end{array}$ \\
\hline Technical features & $\begin{array}{l}\text { - Inaccuracy or lack of source data } \\
\text { - Software imperfection } \\
\text { - The lack of a databank of 3D models of engineering solutions for } \\
\text { - structures and equipment } \\
\text { - Non-standard objects requiring non-standard solutions } \\
\text { - Inconsistency of actual exploitation conditions with model }\end{array}$ \\
\hline
\end{tabular}

The analysis made it possible to take into account the problems existing in our country that impede the development of digital technologies during the exploitation of buildings and to propose an algorithm for generating and updating data on changes in the state of the 
building. A technical passport must be issued for each capital construction project. It reflects the results of a technical inventory. According to the legal regulation, a technical inventory and, accordingly, updating the technical passport must be carried out every five years, entering data on the change in the wear of the building [19-21]. This process requires financial and human resources, as it is necessary to perform repeated surveys of buildings, including measurements and manual calculations. Exploitation efficiency drops sharply also because often the technical documentation for buildings is either completely absent or partially unsuitable for use. Therefore, the creation of an information model of a building can greatly facilitate both the process of technical inventory and increase exploitation efficiency and get rid of the problem of storing information in paper form.

The selection criteria for a particular exploitation measure, which are presented in the building passport, are 3 characteristics:

- technical condition of the facility, the general criterion of which is the amount of physical deterioration of the building $I_{f}$;

- functional mismatch of the facility with modern requirements, the general criterion of which is the amount of obsolescence building $I_{m}$;

- the level of energy resources consumed, the general criterion of which is the deviation of the actual specific heat energy consumption from the normative $\Delta q_{h}$.

Then proposed by the author the total indicator $k_{i q}$, allowing you to make a decision on the choice of exploitation measures can be determined using matrices:

$$
k_{i q}=f\left(I_{f} ; I_{m} ; \Delta q_{h}\right)
$$

In the 1st order matrix, the influence of physical and moral depreciation on decision making is established. The 2nd order matrix takes into account the level of resources consumed. Moreover, in accordance with regulatory requirements, the following gradation is established for the criteria (table. 2).

Table 2. Ranking criteria for the selection of exploitation measures.

\begin{tabular}{|c|c|c|c|c|c|}
\hline $\begin{array}{c}\text { Physical } \\
\text { deterioration } \\
\text { of the } \\
\text { building } \\
\boldsymbol{I}_{\boldsymbol{f}}\end{array}$ & $\begin{array}{c}\text { Class } \\
\text { physical } \\
\text { deterioration } \\
\text { of the } \\
\text { building }\end{array}$ & $\begin{array}{c}\text { Obsolescence } \\
\text { of building } \\
\boldsymbol{I}_{\boldsymbol{m}}\end{array}$ & $\begin{array}{c}\text { Class } \\
\text { obsolescence } \\
\text { of building }\end{array}$ & $\begin{array}{c}\text { Heat } \\
\text { energy } \\
\text { deviation } \\
\boldsymbol{\Delta} \boldsymbol{q}_{\boldsymbol{h}}\end{array}$ & $\begin{array}{c}\text { Energy efficiency } \\
\text { building class }\end{array}$ \\
\hline$\leq 10 \%$ & 1 & $0 \%$ & 1 & $<-15 \%$ & $\mathrm{~A}, \mathrm{~B}$ \\
\hline $11-20 \%$ & 2 & $\leq 30 \%$ & 2 & $\begin{array}{c}\geq-15 \% \\
<+15 \%\end{array}$ & $\mathrm{C}$ \\
\hline $21-30 \%$ & 3 & $31-70 \%$ & 3 & $\geq+15 \%$ & $\mathrm{D}, \mathrm{E}$ \\
\hline $31-60 \%$ & 4 & $>70 \%$ & 4 & & \\
\hline$>60 \%$ & 5 & \multicolumn{3}{|r|}{} &
\end{tabular}

The following scale for the selection of exploitation measures is established: $\mathrm{I}_{\mathrm{t}}$ maintenance; $\mathrm{II}_{\mathrm{t}}$ - current repair; $\mathrm{III}_{\mathrm{t}}$ - selective overhaul; $\mathrm{IV}_{\mathrm{t}}$ - comprehensive overhaul; $\mathrm{V}_{\mathrm{t}}$ - reconstruction, modernization; $\mathrm{VI}_{\mathrm{t}}$ - economic justification for the restoration of a building or demolition. The selection is made on the basis of a matrix sequential comparison (Fig. 2).

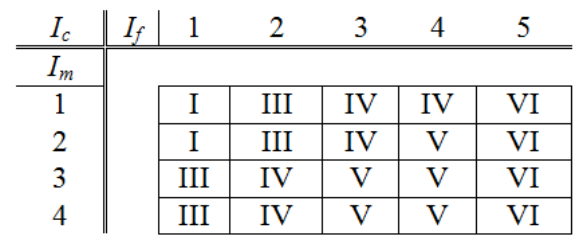

\begin{tabular}{|c|c|c|c|c|c|c|c|}
\hline$k_{i q}$ & $I_{c}$ & I & II & III & IV & V & VI \\
\hline$\Delta q_{h}$ & & & & & & & \\
\hline $\mathrm{A}, \mathrm{B}$ & & $\mathrm{I}_{\mathrm{t}}$ & $\mathrm{II}_{\mathrm{t}}$ & - & - & - & - \\
\hline $\mathrm{C}$ & & $\mathrm{I}_{\mathrm{t}}$ & $\mathrm{II}_{\mathrm{t}}$ & $\mathrm{III}_{\mathrm{t}}$ & $\mathrm{IV}_{\mathrm{t}}$ & $V_{t}$ & $\mathrm{VI}_{\mathrm{t}}$ \\
\hline $\mathrm{D}, \mathrm{E}$ & & $\mathrm{III}_{\mathrm{t}}$ & $\mathrm{III}_{\mathrm{t}}$ & $I V_{t}$ & $I V_{t}$ & $V_{t}$ & $\mathrm{VI}_{\mathrm{t}}$ \\
\hline
\end{tabular}

Fig. 2. Matrices of the 1st and 2nd order for deciding on the choice of exploitation measures. 
Thus, the algorithm for generating and updating data on changes in the state of a building is an electronic form of a building passport made using digital technologies (Fig. 3).

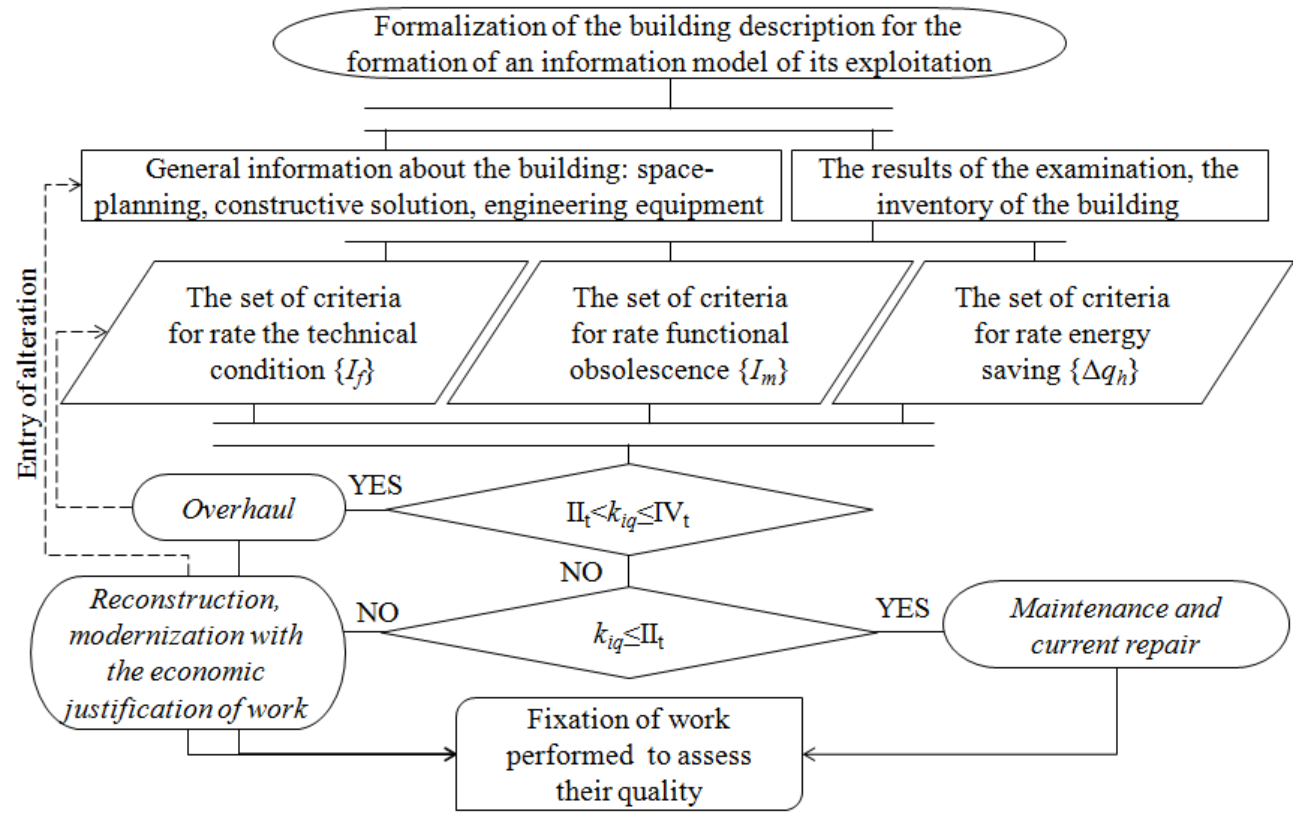

Fig. 3. Algorithm for generating data on the condition of the building and assessing its changes as part of the development of the exploitation program.

Such an approach will make it possible to repeatedly increase the speed of information search and its analysis, and will make it possible to get rid of generalized indicators of building wear, while increasing the accuracy of the wear assessment of each individual engineering system, equipment and structure as well as consumed resources. This will increase the efficiency of current and overhaul projects. Thanks to the information model of building exploitation, the managing organization will have accurate data on the volume of work, each project will be well calculated from an economic point of view. The organization of repair work and the supply of building materials will be transparent and accurate in time, and the monitoring of the work will be carried out in real time, daily. As a result, upon completion of repair work, all information will be stored in the information model, which will allow you to quickly access it in cases of need during operation, in an emergency or other problems.

At the final stage of the study, a methodology for the formation of the exploitation program necessary for the effective management of the technical condition of the building is proposed (Fig. 4). The exploitation program is based on the following constituents:

- measuring system (criteria, parameters);

- information system (databases and data banks of various information, for example, technical, legal, environmental, economic, etc.);

- system for modeling parameters;

- parameter optimization system;

- parameter forecasting system;

- decision making system with risk assessment. 


\section{Discussion}

The significance of the obtained results lies in the fact that the proposed methodology for the formation of exploitation programs allows, on the one hand, to ensure the quality of operation by taking specific measures to prevent premature wear and reduce additional exploitation costs. On the other hand, operational programs can be introduced into the system of strategic sustainable development of cities based on digital technologies to solve the priority tasks energy saving set by the Government of the Russian Federation.

\begin{tabular}{|c|c|c|}
\hline Event type & Methods & Information \\
\hline Surveys, investigations at accident & Visual instrumental & Type of construction \\
\hline sites & visual instrumental & Technical condition \\
\hline Sample selection & Microscopy & Type of damage \\
\hline Laboratory research & Physical chemicals & $\begin{array}{c}\text { Material structure } \\
\text { The composition of the environment }\end{array}$ \\
\hline $\begin{array}{l}\text { Systematization of results: the } \\
\text { formation of a cumulative block of } \\
\text { information }\end{array}$ & Analytic & $\begin{array}{c}\text { Information block data: } \\
\text { A- reference } \\
\text { B - experimental }\end{array}$ \\
\hline Results analysis & System analysis & Type and causes of failures \\
\hline $\begin{array}{l}\text { Formation of an analytical block of } \\
\text { information }\end{array}$ & $\begin{array}{l}\text { Software: } \\
\text { digital technology }\end{array}$ & $\begin{array}{l}\text { Datablock: for } \\
\text { diagnostics and } \\
\text { prognosis }\end{array}$ \\
\hline Diagnosis & Expert methods & Destruction rate \\
\hline Prognosis & Expert methods & mage risk assessment \\
\hline Recommendations & digital technology & $\begin{array}{c}\begin{array}{c}\text { Selection of corrective actions, } \\
\text { development of an exploitation } \\
\text { program }\end{array} \\
\end{array}$ \\
\hline
\end{tabular}

Fig. 4. The block diagram of the methodology for the formation of the exploitation program.

Of course, there are certain difficulties that must be solved before implementing a digital exploitation program In particular the issue of developing compatible software and training specialists who would have the necessary competencies for the processing and use of these software products is an acute issue.

Also, undoubtedly, the introduction of digital technologies in housing and communal services is a costly undertaking. One of the suggestions for solving this problem is the partial allocation of funds from the capital repair program.

It is also advisable to apply two approaches to the formation of an information model of building exploitation. In the case of the construction of a new facility, it is necessary to legislatively consolidate the formation of the model of the exploitation program at the design stage, for example, by creating a special body that will control their formation at the construction stage and their transfer from developers to owners.

In the case of existing buildings, especially those with significant deterioration, scanning and digitization of the object will be inappropriate. On the other hand, the specifics of the existing housing stock are such that there may not be many maintenance programs due to standard constructions. This means that it is possible to develop standardized exploitation programs that can easily be replicated to objects of similar series, making minor changes and refinements during exploitation activities. 
In this case, the process of transition to digital technologies will be carried out in a fairly short time and in the future there will be no need to create models for existing buildings. Experts say about $30 \%$ of the capital repair fund savings due to their implementation. In addition, in the future, owners will have the opportunity to really control the volume, timing and quality of work based on the exploitation program.

\section{Conclusions}

Obviously, in the concept of sustainable urban development, one of the leading roles is played by digital technologies, which can be used, inter alia, to create information programs for the exploitation of buildings. Such a program naturally fits into the concept of "green" construction, since it allows one of the most important criteria for the quality of the living environment to be provided - control of safety, comfort and energy efficiency.

In the process of carrying out the research, the problems of introducing digital technologies at the stage of building exploitation were studied and classified, and an algorithm for the formation of a building exploitation program was designed to update data on changes in the technical condition of structures and systems as well as data on energy consumption. The practical significance of the work lies in the development of criteria and method for the formation of the exploitation program. The novelty of the study lies in the possibility of applying the methodology for the formation of the exploitation program both for monitoring and ensuring the safe operation of the building, and for assessing the quality of work of managing organizations.

\section{References}

1. E. Voskresenskaya, L. Vorona-Slivinskaya, L. Achba, E3S Web of Conf. 91, 05010 (2019)

2. M. Dement'eva, A. Dement'eva, MATEC Web of Conf. 170, 01079 (2018)

3. V. G. Borkovskaya, Advanced Materials Research 945, 22, 3012-3015 (2014)

4. A. Antipova, D. Eremina, T. Shakirova, MATEC Web of Conf. 170, 01005 (2018)

5. P. Garibin, E. Ol'khovik, E3S Web of Conf. 135, 01022 (2019)

6. A. Subbotin, A. Melkumyan, V. Khuriev, E3S Web of Conf. 135, 03008 (2019)

7. Y. Vertakova, I. Izmalkova, E. Leontyev, E3S Web of Conf. 138, 02005 (2019)

8. V. G. Borkovskaya, E. Degaev, I. Burkova, MATEC Web of Conf. 193, 05027 (2018)

9. D. Shutin, A. Malakhov, K. Marfin, MATEC Web of Conf. 251, 03005 (2018)

10. M. Dement'eva, I. Terekhin, A. Lebedeva, MATEC Web of Conf. 251, 06012 (2018)

11. V. G. Borkovskaya, MATEC Web of Conf. 251, 06025 (2018).

12. P. Chelyshkov, K. Aralkin, MATEC Web of Conf. 251, 03059 (2018)

13. Y. Latief, R. A. Machfudiyanto, B. S. Soepandji, K. Aldesty, R. Aldesty, MATEC Web of Conf. 195, 06005 (2018)

14. M. Dement'eva, A. Dement'eva, E3S Web of Conf. 33, 03067 (2018)

15. A. Mottaeva, A. Borisova, E3S Web of Conf. 138, 02015 (2019)

16. E. Derbasova, E. Bialeckaia, R. Mukanov, V. Svintsov, E3S Web of Conf. 135, 01014 (2019)

17. S. A. Sokolova, K. V. Borisova, Fundamental research 11-4, 870-874 (2016)

18. V. M. Kaziev, E.V. Kaziev, Fundamental research 4, 75-80 (2018) 
19. D. I. Emelyanov, N. A. Ponyavina, E. A. Chesnokova, N. V. Bredikhina, Proceedings of the Southwest State University, 3(78), 22, 40-50 (2018)

20. M. Dement'eva, IOP Conf. Series: Earth and Environmental Sci. 90, 012052 (2017)

21. B. Nowogonska, IOP Conf. Ser.: Mater. Sci. Eng. 471, 112034 (2019) 